\title{
Biologic Width Dimensions in Diseased And Healthy Periodontium - A Clinico-Radiographic Study
}

\author{
Rajesh KS' ${ }^{1}$, Sonal Deepak Ganji², Shashikanth Hegde, Arun Kumar MS ${ }^{4}$
}

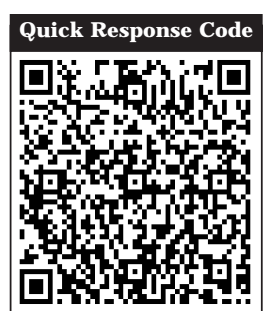

doi: $10.5866 / 2016.8 .10003$

1-4Department of Periodontics

Yenepoya Dental College

Mangalore, India

\begin{abstract}
:
Background: Biologic width (BW) is an important clinical concept in restorative dentistry and periodontics. Very few studies have been done on the measurement of BW in humans with clinically diagnosed periodontitis.

Aim: To determine dinical biologic width in chronic generalized periodontitis and in subjects with healthy periodontium and compare it with previously established histologic dimensions of biologic width.

Materials and Methods: A total of 54 patients (37 males and 17 females), aged 30 to 60 years with (a) healthy periodontium (b) chronic generalized periodontitis were enrolled in this crosssectional study conducted over a period of 1 year at Department of Periodontology, Yenepoya Dental college, Mangalore. Parameters included the number of teeth present, gingival index, CPI index, probing pocket depth and clinical attachment level. Full mouth intraoral periapical radiographs were taken using long cone paralleling technique. The dinical biologic width was determined from the most coronal level of dinical attachment to the crest of the alveolar bone on proximal surfaces.

Results: The clinical biologic width in subjects with chronic generalized periodontitis was significantly lower than healthy subjects ( $p<0.001)$ and previously reported histol ogic BW $(p<0.001)$. For all evaluable proximal sites, the mean clinical biologic width in chronic periodontitis subjects was $1.92 \mathrm{~mm}$ versus the mean clinical biologic width of $2.36 \mathrm{~mm}$ in healthy subjects and mean histologic biologic width of $2.04 \mathrm{~mm}$.

Conclusion: The mean clinical biologic width in subjects with chronic generalized periodontitis seemed to be significantly lower than mean biologic width in healthy subjects as well as previously reported.
\end{abstract}

Key words: Biologic width, dentogingival unit, periodontitis

\section{INTRODUCTION}

The phenomenon of the establishment of a zone of biologic width (BW) is an important clinical concept in restorative dentistry and periodontics for many years.1, 2 The supracrestal soft tissue attachment of the periodontal tissues to the tooth/ root surface has been termed as the BW. ${ }^{3}$ In other words, BW refers to the height of the dento-gingival attachment apparatus necessary for a healthy existence of boneand soft tissue from the most apical extent of a dental restoration. The dimensions of the BW having an average value of $2.04 \mathrm{~mm}$ is 
considered to be norm for most patients and most teeth, although significant variations especially in the length of the epithelial attachment can occur., 4

Although supracrestal connective tissue attachment is variable in nature, this component of the periodontal support that may provide periodontal stability to teeth that lack alveolar bone support as well as providing an unusually large BW. ${ }^{5}$ But these values of BW measurements should not be extrapolated for use in pathologic situations as they were taken from healthy periodontium. ${ }^{6}$ It has been believed for many years that the distance from the base of the sulcus to the crest of the alveolar bone remains generally constant, with mean values of 1.94 to $1.97 \mathrm{~mm}^{7,8}$

Periodontal disease is generally chronic in nature and shows slow progression. Various factors such as host- bacterial interaction, various environmental factors, acquired risk factors such as systemic diseases and conditions, smoking and in some cases altered expression of inflammatory genotype are the causes for progression of the disease resulting in severe bone and attachment loss at an early age. ${ }^{6}$

A variation in BW in cases of periodontitis provides significant implications for the selection of surgical or non-surgical approaches. Various studies have reported that surgical intervention in sites with shallow probing depths resulted in post-surgical loss of attachment at that site. ${ }^{9-14}$ Very few studies have evaluated the dimension of BW in humans with clinically diagnosed periodontitis. ${ }^{15}$ So, the purpose of the present study is to determine whether the previously evaluated histologic dimensions of the BW apply in untreated cases of chronic generalized periodontitis and to understand the influence of these BW variations on approach to therapy.

\section{METHODS AND MATERIALS}

A total of 54 subjects ( 37 males and 17 females) between the age ranging from 30 to 60 years were enrolled in this cross-sectional study conducted over a period of one year at outpatient Department of Periodontology, Yenepoya Dental College, Mangalore. The study protocol was approved by Ethics Committee of the university and informed consent was obtained from all the patients. All patients were provided with verbal explanation of the nature of the study. The following inclusion criteria were considered: Subjects with clinically healthy periodontium constituted group $A$, subjects with chronic generalised periodontitis constituted group B and each subject having at least 20 erupted natural teeth. Exclusion criteria included subjects: 1) with systemic diseases; 2) taking antibiotic therapy within the past 3 months; 3) who received non-surgical periodontal therapy 3 months prior to study; 4) who received surgical periodontal therapy in the past 12 months; and 5) pregnant females.

Data was collected by performing clinical and radiographic examination to determine clinical BW. For each patient, the periodontal examination was performed by a single examiner, and following parameters such as Gingival index (Loe and Silness 1963), Community periodontal index (CPI), fullmouth recording of probing depths (PDs) and clinical attachment levels (CALs) at six sites per tooth, except third molars were recorded using a millimetre calibrated University of North Carolina (UNC) 15 probe (Figure 1). ${ }^{16,17}$

The clinical biologic width was determined from the most coronal level of clinical attachment to the crest of the alveolar bone on proximal surfaces. Full mouth series of periapical radiographs were taken for each subject using the long cone paralleling technique by Satelec Acteon X-mind AC x-ray unit. All radiographs were exposed with settings at 70 kilovolt and $8 \mathrm{~mA}$. IOPA were captured with No. two size, Ektaspeed films (Eastman, Kodak, Rochester, NY, USA) using paralleling technique with the help of Rinn XCP holder (Rinn Corporation, Elgin, III, USA) as per the criteria given by $\mathrm{J}$ orgenson $\mathrm{T}$ et al. ${ }^{16}$ The focal spot was concentrated at $0.7 \mathrm{~mm}$ and the exposure time was set to $0.4 \mathrm{sec}$. Films were processed under standardized conditions using an Velopex automatic processor. Radiographs were digitized by projecting each $x$-ray film onto a LED $x$-ray film viewer. All radiographs were placed in slide holders on a light viewing box and photographed using a Canon IXUS 230 HS digital camera (Canon Inc., NY, USA) with 8x zoom, 28mm wide lens, 12.1 Megapixel High Sensitivity CMOS Sensor and Optical I mage Stabiliser with I ntelligent IS with a recording image of $1024 \times 768$ pixels.

The Canon camera images were taken at the same camera-radiograph distance with a mini tripod. Identical illumination was used throughout with the radiographs placed at the same location on the light box (Figure 2). Digital camera images were saved as J oint Photographic Experts Group (J PEG) files. Digital images were loaded directly onto a Lenovo L 430 ThinkPad laptop with a 14 inch screen. 
I mages were opened using Micro Dicom viewer software (Version 0.7.7 Sofia, Bulgaria). The full screen was used with a black background for each image.

The radiographs were scanned to obtain digitalized images to measure the crestal bone level (CBL that is the distance from cementoenamel junction (CEJ) to the alveolar crest) on proximal surfaces using computerized software (Figure 3). Only proximal surfaces were used in the analysis, and mean values of the buccal and lingual proximal clinical measures for CAL were used for comparison with BL at each evaluated radiographic surface. Clinical BW is defined as the distance from the most coronal level of the CAL to the CBL. As CEJ is used to calculate CAL and CBL, clinical BW was calculated by subtracting the CAL from CBL.

\section{STATISTICAL SIGNIFICANCE}

The data obtained were subjected to descriptive and comparative statistical analysis. Data was summarized as mean and standard deviation for continuous variables. The Student t-test was used for comparing the means of quantitative variables. Chi-square test, Fisher's exact test and MannWhitney $U$ test were used to determine whether the differences in proportions and means were statistically significant. Pearson's correlation coefficient was computed to measure degree of correlation between PD, CAL, BL and BW. All analyses were performed using Statistical Program for Social sciences Version 20.0 (SPSS) software. The differences were considered to be statistically significant only for $\mathrm{p} \varangle 0.05$ and highly significant for $\mathrm{p} \lessdot 0.001$.

\section{RESULTS}

A total of 54 subjects in the age group of 30-60 years were included in the study and the subjects were divided into control group (33.89 \pm 4.06$)$ and test group (46.44 \pm 7.64$)$. Assuming a e error of 0.05 and $95 \%$ confidence interval, the power of the study was found to be $80 \%$. Table 1 reveals that the mean gingival index scores were significantly higher in group B compared with group A $(p<0.001)$. The results of Community Periodontal I ndex (CPI) showed that code $1,2,3,4$ was found to be statistically significant because $p$ value was 0.0001 for all the codes respectively (Table 2 ). The results of clinical attachment loss (CAL) showed that code 0, 1, 2, 3, 4 were statistically significant because $p$ value was 0.0001 respectively. CPI Code 1 was more in group $A$ whereas code 2, 3, 4 was more in group B suggestive of periodontally healthy subjects in group $A$ and subjects with chronic periodontitis in group B (Table 3). The results showed that for all evaluable proximal sites, mean clinical biologic width in healthy subjects was significantly higher than mean clinical biologic width in subjects with chronic generalized periodontitis ( $p<0.001$ ) as represented in table 4. The results showed that mean clinical biologic width in group A was significantly higher than previously reported biologic width $(p<0.001)$ whereas mean clinical biologic width in group $B$ was found to be significantly lower than previously reported biologic width ( $p=0.034$ ) as represented in table 5. For all sites combined, Pearson's correlation ( $r$ ) in table 6 shows a significant positive correlation ( $p<0.001$ ) between PD and CAL. Further, a negative correlation was found between BW, PD and CAL ( $p<0.05)$. A negative correlation was found between $B W$ and $B L$, which was statistically significant ( $p<0.001)$ (table 7).

\section{DISCUSSION}

The present study was aimed to compare clinical BW in chronic periodontitis and periodontally healthy subjects with previously reported histologic BW. The study design involved patients with chronic generalized periodontitis $(n=27)$ and healthy subjects ( $n=27$ ). The study included measurement of clinical parameters and radiographic parameters.

The biologic width is defined as the dimension of the soft tissue, which is attached to the portion of the tooth coronal to the crest of the alveolar bone. This term was based on the work of Garguilo et al (1961) who measured dentogingival components in 287 individual teeth from 30 autopsy specimens and established that there is definite proportional relationship between alveolar crest, the connective tissue attachment, the epithelial attachment and the sulcus depth. They determined that the epithelial attachment length was $0.97 \mathrm{~mm}$, and the connective tissue attachment length was $1.07 \mathrm{~mm}$, so the combined dimension of the connective tissue attachment and the junctional epithelium (the normal biologic width) averages $2.04 \mathrm{~mm}$ in a healthy periodontium. The most constant part of dentogingival junction dimension was the connective tissue attachment and the most variable part was the epithelial attachment. ${ }^{[4]}$ The histologically determined the biologic width in adult human cadaver jaws obtained measurements of $1.14 \pm 0.49$ $\mathrm{mm}$ for epithelial attachment, $0.77 \pm 0.32 \mathrm{~mm}$ for 

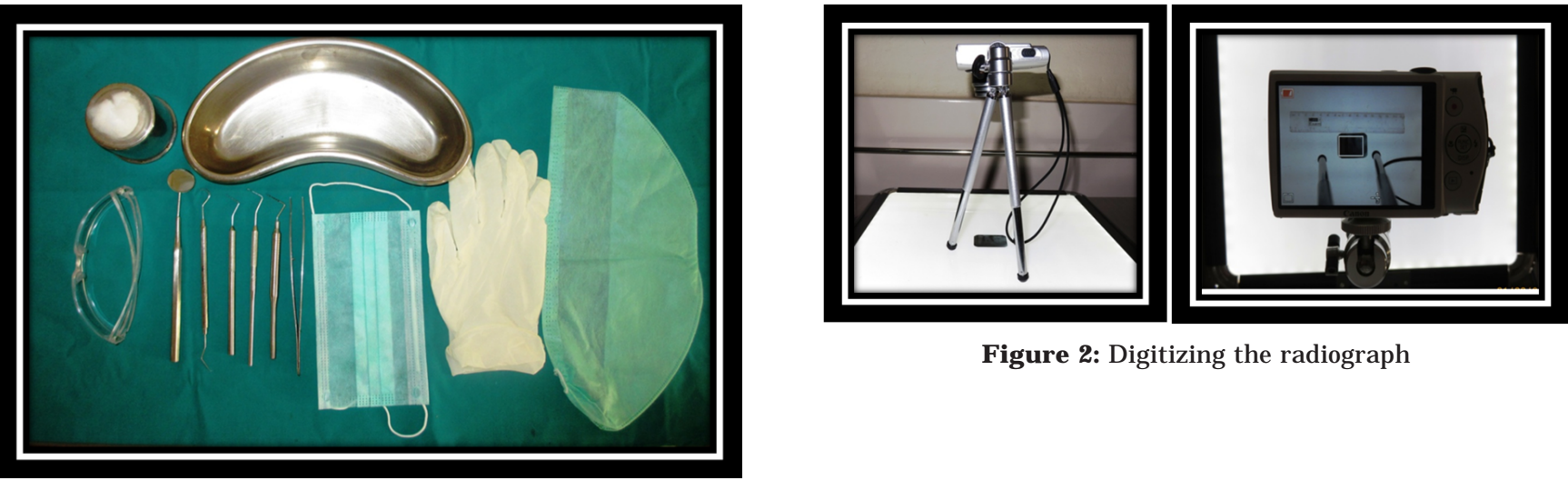

Figure 2: Digitizing the radiograph

Figure 1: Armamentarium

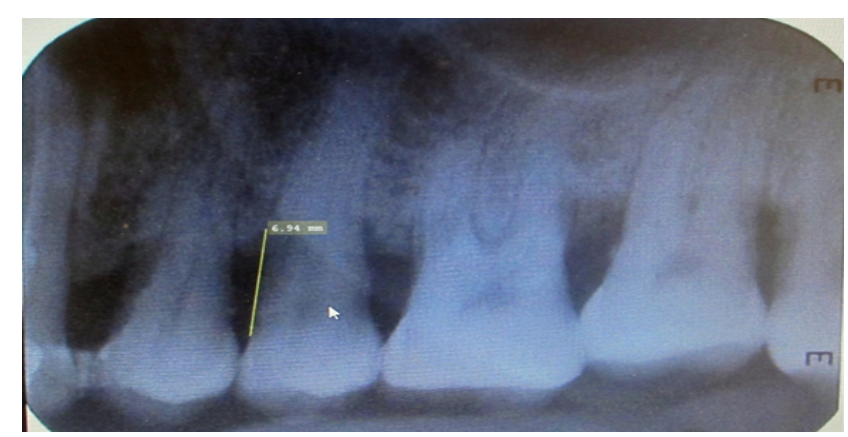

Table 1: Mean Gingival Index of Test group and Control group

Original tables:

GI

\begin{tabular}{|l|l|r|r|r|r|r|r|r|}
\hline Group & N & Minimum & Maximum & Mean & $\begin{array}{c}\text { Std. } \\
\text { Deviation }\end{array}$ & Median & $\begin{array}{c}\text { Mannwhit } \\
\text { ney test Z } \\
\text { value }\end{array}$ & $\mathrm{p}$ \\
\hline Group A & 27 & .20 & .95 & .64 & .24 & .66 & 6.31 & .000 \\
Group B & 27 & 1.00 & 2.45 & 1.90 & .45 & 2.00 & & HS \\
Total & 54 & .20 & 2.45 & 1.27 & .73 & .98 & & \\
\hline
\end{tabular}

Table 2: Distribution of subjects according to the Community periodontal index CPI codes in relation to probing depth

\begin{tabular}{|c|c|c|c|c|}
\hline & & \multicolumn{2}{|c|}{ Group } & \multirow[b]{2}{*}{ Total } \\
\hline & & Group A & Group B & \\
\hline \multirow[t]{8}{*}{ PD } & 1 & 8 & 0 & $8^{*}$ \\
\hline & & $29.6 \%$ & $.0 \%$ & $14.8 \%$ \\
\hline & 2 & 15 & 1 & $16^{*}$ \\
\hline & & $55.6 \%$ & $3.7 \%$ & $29.6 \%$ \\
\hline & 3 & 4 & 2 & 6 \\
\hline & & $14.8 \%$ & $7.4 \%$ & $11.1 \%$ * \\
\hline & 4 & 0 & 24 & $24^{*}$ \\
\hline & & $.0 \%$ & $88.9 \%$ & $44.4 \%$ \\
\hline \multirow{2}{*}{\multicolumn{2}{|c|}{ Total }} & 27 & 27 & $54^{*}$ \\
\hline & & $100.0 \%$ & $100.0 \%$ & $100.0 \%$ \\
\hline
\end{tabular}

Fishers exact test $* \mathrm{p}=0.0001$, HS
Table 3: Distribution of subjects according to the Community periodontal index CPI codes in relation to loss of attachment

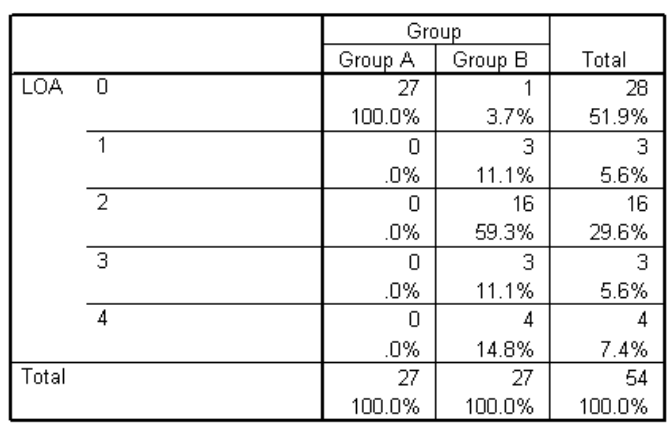

Fishers exact test $p=0.0001$, HS 
Table 4: Comparison of mean and standard deviation of clinical biologic width in group A and group B

\begin{tabular}{|c|c|c|c|c|c|c|c|c|}
\hline Group & $\mathrm{N}$ & Minimum & Maximum & Mean & Std. Deviation & Median & $\begin{array}{l}\text { Mannwhit } \\
\text { ney test } Z \\
\text { value }\end{array}$ & $p$ value \\
\hline Group A & 27 & 2.273 & 2.493 & 2.364 & .052 & 2.347 & 5.614 & .000 \\
\hline Group $\mathrm{B}$ & 27 & 1.356 & 2.452 & 1.925 & .267 & 2.009 & & HS \\
\hline Total & 54 & 1.356 & 2.493 & 2.144 & .292 & 2.298 & & \\
\hline
\end{tabular}

Table 5: Comparison of clinical biologic width of group A and group B with previously reported biologic width

Parameter: BIOLOGIC WIDTH

Over all

\begin{tabular}{|l|r|r|r|l|}
\hline \multirow{2}{*}{} & \multicolumn{5}{|c|}{ Test Value $=2.04$} \\
\cline { 2 - 5 } & & & & \\
Group & Mean Difference & $\mathrm{t}$ & $\mathrm{p}$ & \\
\hline Group $\mathrm{A}$ & .3240 & 32.530 & .000 & $\mathrm{HS}$ \\
Group $\mathrm{B}$ & -.1154 & 2.243 & .034 & $\mathrm{sig}$ \\
\hline
\end{tabular}

Table 6: Correlation between BW,PD \& CAL

\begin{tabular}{|c|c|c|c|c|}
\hline \multicolumn{5}{|c|}{ Correlations } \\
\hline & & BW & PD & CAL \\
\hline BW & $\begin{array}{l}\text { Pearson Correlation } \\
\text { Sig. (2-tailed) } \\
\text { N }\end{array}$ & $\begin{array}{l}1 \\
54\end{array}$ & $\begin{array}{c}-.294^{\star} \\
.031 \\
54\end{array}$ & $\begin{array}{c}-.631^{\star \star} \\
.000 \\
54\end{array}$ \\
\hline PD & $\begin{array}{l}\text { Pearson Correlation } \\
\text { Sig. (2-tailed) } \\
\mathrm{N}\end{array}$ & $\begin{array}{c}-.294^{*} \\
.031 \\
54\end{array}$ & $\begin{array}{r}1 \\
54\end{array}$ & $\begin{array}{c}.659^{\star *} \\
.000 \\
54\end{array}$ \\
\hline CAL & $\begin{array}{l}\text { Pearson Correlation } \\
\text { Sig. (2-tailed) } \\
\text { N }\end{array}$ & $\begin{array}{c}-.631^{* *} \\
.000 \\
54\end{array}$ & $\begin{array}{c}.659^{* x} \\
.000 \\
54\end{array}$ & $\begin{array}{r}1 \\
54\end{array}$ \\
\hline
\end{tabular}

${ }^{*}$. Correlation is significant at the 0.05 level (2-tailed).

${ }^{* *}$. Correlation is significant at the 0.01 level (2-tailed).

Table 7: Correlations between BW \& BL

Correlations

\begin{tabular}{|ll|r|r|}
\hline & & \multicolumn{1}{|c|}{ BW } & \multicolumn{1}{|c|}{ BL } \\
\hline BW & Pearson Correlation & 1 & $-.634^{* *}$ \\
& Sig. (2-tailed) & & .000 \\
& $N$ & 54 & 54 \\
\hline BL & Pearson Correlation & $-.634^{* *}$ & 1 \\
& Sig. (2-tailed) & .000 & \\
& N & 54 & 54 \\
\hline
\end{tabular}

**. Correlation is significant at the 0.01 level (2-tailed). 
connective tissue attachment, $2.17 \mathrm{~mm}$ for biologic width, $1.07 \mathrm{~mm}$ for junctional epithelium, and 1.10 $\mathrm{mm}$ for the connectivetissue were reported by Vacek et al (1994) and Xie et al (2007). ${ }^{18,19}$

There are no comprehensive evaluations of BW in advanced cases of periodontitis where significant changes in connectivetissue and bone have occurred. Therefore, the present study took advantage of baseline data obtained as part of an intervention in subjects with chronic generalized periodontitis to examine the changes in BW that might occur in periodontitis. In the present study, the first observation was that the average clinical biologic width in cases of chronic generalized periodontitis was $1.92 \mathrm{~mm}$, which was lower than the histologic biologic width previously reported for subjects not demonstrating significant periodontal pathology. Mean clinical biologic width in group B was found to be significantly lower than previously reported biologic width $(p=0.034)$. Papananou et al (1989) reported strong correlation $(r=0.80)$ between radiographic assessment of alveolar bone loss and changes in CAL. ${ }^{20}$ Also, Clerehugh \& Lennon (1986) [21] reported a similar correlation (contingency coefficient of 0.51). ${ }^{21}$ Conversely, Goodson et al (1993), Mann et al (1985) and Machtei et al (1997), in a similar study of the relationship between clinical and radiographic detection of periodontal disease progression, reported poor agreement between the two variables. ${ }^{22-24}$

It was seen that the mean clinical biologic width in subjects with healthy periodontium $(2.36 \mathrm{~mm})$ was significantly greater than the mean histologic biologic width reported previously $(2.04 \mathrm{~mm})$. Similar observations were made by Novak et al (2008) and Gaddale et al (2015) Alpiste-l llueca et al (2004), Al-Rasheed et al (2005), Galagali and Gontiya et al (2012) obtained mean biologic of 2.00 $+/-0.72,1.24 \mathrm{~mm}$ and $1.72 \mathrm{~mm} .{ }^{15,25-28} \mathrm{~F}$ or all evaluable proximal sites, the mean clinical biologic width was $2.14 \mathrm{~mm}$ versus the mean histologic biologic width of $2.04 \mathrm{~mm}$ which is consistent with the findings of previous studies done by Novak et al (2008) and Gaddale et al (2015).5, 25 These results corroborate the notion that the dimensions of the dentogingival unit are highly variable in humans. The dimensions of biologic width seem to differ with respect to periodontal health and in untreated chronic periodontitis patients.

An examination of correlation coefficients confirmed our initial observations that for sites with chronic periodontitis, CAL was significantly correlated with $\mathrm{BL}$ and showed an inverse relationship with $B W$ which means as $C A L$ and $B L$ increases, BW decreases. This was observed as bone levels are used in the determination of the BW. Also, the results showed that sites with shallow PDs and least CAL had the greatest BW in case of healthy subjects. This observation provides significant implications for the selection of surgical or nonsurgical approaches in the treatment of patients with chronic periodontitis.

In our study, mean gingival index for the chronic periodontitis group was higher compared to the control group, which was statistically highly significant $(p<0.001)$. This finding is in accordance with previous studies done by Lang et al (1990), Albandar et al (1998), Schatzle et al (2003). ${ }^{29-31}$ Claffey et al (1995) reported that for higher risk patients, bleeding on probing at maintenance examinations may be a useful indicator of subsequent deterioration at a site level. ${ }^{32}$

In the present study, distribution of subjects according $\mathrm{CPI}$ index codes 1 and 2 in relation to PD and CAL was higher in healthy subjects than chronic periodontitis group, which was statistically highly significant $(p<0.001)$ and distribution of subjects according $\mathrm{CPI}$ index codes $3 \& 4$ in relation to $\mathrm{PD}$ and $C A L$ was higher in chronic periodontitis group as compared to healthy subjects, which was statistically highly significant $(p<0.001)$. These findings are similar to the studies conducted by Brown at al (1993), Kaimenyi et al (1982), Pilot et al (1986), Benigeri et al (2000). ${ }^{33-36}$

Results also showed that there was no statistical difference between studied groups in relation to smokers ( $p=0.054)$. There were $57.4 \%$ non-smokers and $42.6 \%$ smokers among group $A$ and group $B$ respectively.

\section{CONCLUSION}

Within the limitations of the study, it may be concluded that clinical BW in chronic periodontitis patients was significantly lower than the previously reported histologic BW. Mean clinical BW was significantly higher than previously reported histologic BW. Thus, there is significant intra- and inter individual variability in the dimensions of the biologic width. The dimensions of the biologic width seem to be affected by periodontal diseases. 


\section{REFERENCES:}

1. Gargiulo A, Krajewski J , Gargiulo M. Defining biologic width in crown lengthening. CDS Rev 1995; 88:20-3.

2. Robbins J W. Tissue management in restorative dentistry. Funct Esthet Restor Dent 2007; 1:40-3.

3. Ingber J S, Rose LF, Coslet J G. The "biologic" width -A concept in periodontics and restorative dentistry. Alpha Omegan 1977; 70:62-5.

4. Gargiulo AW, Wentz FM, Orban B. Dimensions and relations of the dento-gingival junction in humans. J Periodontol 1961; 32:261-7.

5. Novak MJ , Polson AM, Caton J , Freeman E, Meitner S. A periodontal attachment mechanism without alveolar bone. Case report. J Periodontol 1983; 54:112-8.

6. Page RC, Kornman KS. The pathogenesis of human periodontitis: An introduction. Periodontol 2000 1997; 14:911.

7. Stanley HR J r. The cyclic phenomenon of periodontitis. Oral Surg Oral Med Oral Pathol 1955; 8:598-610.

8. Waerhaug J. The gingival pocket. Odontol Tidskr 1952; 60:95-134.

9. Knowles J W, Burgett FG, Nissle RR, Shick RA,Morrison EC, Ramfjord SP. Results of periodontal treatment related to pocket depth and attachment level. Eight years. J Periodontol 1979; 50:225-33.

10. Lindhe J, Westfelt E, Nyman S, Socransky SS, Heijl $L, B$ ratthall G. Healing following surgical/non-surgical treatment of periodontal disease. A clinical study. J Clin Periodontol 1982; 9:115-28.

11. Lindhe J, Westfelt E, Nyman S, Socransky SS,Haffajee AD. Long-term effect of surgical/non-surgical treatment of periodontal disease. J Clin Periodontol 1984; 11:448-58.

12. Pihlstrom BL, McHugh RB, Oliphant TH, Ortiz-Campos C. Comparison of surgical and nonsurgical treatment of periodontal disease. A review of current studies and additional results after $6 \frac{1}{2}$ years. J Clin Periodontol 1983; 10: $524-41$.

13. Pihlstrom BL, Oliphant TH, McHugh RB. Molar and nonmolar teeth compared over $61 / 2$ years following two methods of periodontal therapy. J Periodontol 1984; 55:499504.

14. Ramfjord SP, Caffesse RG, Morrison EC, et al. 4 modalities of periodontal treatment compared over 5 years. J Clin Periodontol 1987; 14:445-52.

15. Novak MJ, Albather $\mathrm{HM}$ and Close J M. Redefining the Biologic Width in Severe, Generalized, Chronic Periodontitis: I mplications for Therapy. J Periodontol 2008; 79:1864-9.

16. J orgenson T, Masood F, Beckerley J M, Burgin C, Parker DE. Comparison of two imaging modalities: $F$-speed film and digital images for detection of osseous defects in patients with interdental vertical bone defects. Dentomaxillofac Radiol 2007; 36:500-5.

17. Loe $\mathrm{H}$ and Silness J. Periodontal Diseases in Pregnancy I. Prevalence and severity. Acta Odontol Scand 1963; 21:53351.

18. Vacek J S, Gher ME, Assad DA, Richardson AC, Giambarresi LI. The dimensions of the human dentogingival junction. Int J Periodontics Restorative Dent 1994; 14:155 65.

19. Xie GY, Chen J H, Wang $\mathrm{H}$ and Wang $\mathrm{YJ}$. Morphological measurement of biologic width in Chinese people. J Oral Sci 2007; 49:197-200.
20. Papapanou PN, Wennstrom J L. Radiographic and clinical assessment of destructive periodontal disease. J Clin Periodontol 1989; 16:609-612.

21. Clerehugh $\mathrm{V}$, Lennon MA. The radiographic measurement of early periodontal bone loss and its relationship with clinical loss of attachment. Br Dent J 1986; 161:141-4.

22. Goodson J M, Haffajee AD, Socransky SS. The relationship between attachment level loss and alveolar boneloss. J Clin Periodontol 1993; 11:348-59.

23. Mann J, Pettigrew $\mathrm{H}$, Beidmann R, Green $\mathrm{P}$, Ship I. I nvestigation of the relationship between clinically detected loss of attachment and radiographic changes in early periodontal disease. J Clin Periodontol 1985; 12:247-53.

24. Machtei EE, Hausman E, Grossi SG, Dunford R, Genco RJ The relationship between radiographic and clinical changes in the periodontium. J Periodontal Res 1997; 32:661-6.

25. Gaddale R, Desai S, Karthikeyan I, Mudda J, Shinde HH and Tapashetti R. Determination of clinical biologic width in chronic generalized periodontitis and healthy periodontium: A clinico-radiographical study. J Indian Soc Periodontol 2015; 19:194-8.

26. Alpiste-lllueca, F. Dimensions of the dentogingival unit in maxillary anterior teeth: a new exploration technique (parallel profile radiograph). Int J Periodontics Restorative Dent 2004; 24:386-96.

27. AI-Rasheed AA, Ghabban W and Zakour A. Clinical biological width dimention around dentition of a selected Saudi population. Pakistan Oral and Dent J r 2005; 25:816.

28. Galagali SR and Gontiya G. Evaluation of an innovative radiographic technique-parallel profile radiography-to determine the dimensions of dentogingival unit. Indian J Dent Res 2011; 22:237-41.

29. Lang NP, Alder R, J oss A, Nyman S. Absence of bleeding on probing. An indicator of periodontal stability. J Clin Periodontol 1990; 17:714-21.

30. Albandar J M, Kingman A, Brown LJ, L oe H. Gingival inflammation and subgingival calculus as determinants of disease progression in early-onset periodontitis. J Clin Periodontol 1998; 25:231-7.

31. Schatzle M, Loe H, Burgin W, Anerud A, Boysen H, Lang NP. Clinical course of chronic periodontitis. J Clin Periodontol 2003; 30:887-901.

32. Claffey $\mathrm{N}$, Egelberg J . Clinical indicators of probing attachment loss following initial periodontal treatment in advanced periodontitis patients. J Clin Periodontol 1995; 22:690-6.

33. Brown LJ, Loe H. Prevalence, extent, severity and progression of periodontal disease. Periodontol 2000 1993; 2:57-71.

34. Kaimenyi J T, Gururaja TR. Periodontal health status of adult population of Kenya and I ndia. Indian Soc Periodontol 1982; 2:17-20.

35. Pilot $T$, Barnes DE, Leclercq MH, McCombie BJ, Sardo Infirri J . Periodontal conditions in adults, 35-44 years of age: An overview of CPITN data in the WHO Global Oral Data Bank. Community Dent Oral Epidemiol 1986; 14:3102.

36. Benigeri $M$, Brodeur J $-M$, Payette $M$, Charbonneau $A$, I smail AI. Community periodontal index of treatment needs and prevalence of periodontal conditions. J Clin Periodontol 2000; 27:308-12. 